\title{
Size assessment in polychaete worms-application of morphometric correlations for common North Atlantic taxa
}

\author{
Barbara Górska (D), ${ }^{1} *$ Sławomira Gromisz, ${ }^{2}$ Maria Włodarska-Kowalczuk (i) ${ }^{1}$ \\ ${ }^{1}$ Marine Ecology Department, Institute of Oceanology Polish Academy of Sciences, Sopot, Poland \\ ${ }^{2}$ Department of Fishieries Oceanography and Marine Ecology, National Marine Fisheries Research Institute, Gdynia, Poland
}

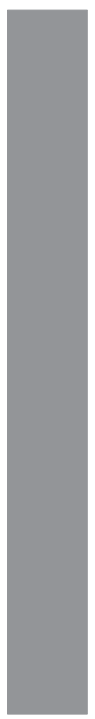

\begin{abstract}
Body size is a basic animal feature that defines its functioning in multispecies assemblages. Polychaetes are numerically dominant components of marine macrobenthos, playing a key role in benthic productivity. They are also the most problematic group regarding body-size assessments due to common fragmentation of fragile bodies during sample processing that inhibits direct assessments of their size and biomass. Here, we present quantified relationships that allow an estimation of the total-body length based on morphometric features (widths of thoracic chaetigers) that remain intact after standard macrobenthic sample treatment. The best-fitted regression equations ( $p<0.001, r$ from 0.41 to 0.99 ) were selected for 28 polychaete families, six orders, two infraclasses, and one subclass based on the measurements on 3580 complete individuals collected in the North Atlantic (Norwegian and Spitsbergen fjords and continental margin). In Capitellidae, Cirratulidae, Oweniidae, and Trichobranchidae, the shapes of the relationships differed among dominant species/genera, and so, specific formula was proposed. The method has been applied to assess the size spectra of macrozoobenthos based on 18 van Veen grab samples collected at six stations in two Spitsbergen fjords. The percentage contribution of complete individuals in polychaete biomass and abundance in size classes varied between $0 \%$ and $43 \%$, with the lowest percentages noted in two dominant families-Cirratulidae and Lumbrineridae. The presented method is likely to be widely applied in studies requiring polychaete individual size assessments (e.g., benthic biomass size spectra, population dynamics, and secondary production).
\end{abstract}

Polychaetes are segmented worms living mainly in marine benthic habitats from intertidal to abyssal depths. The class contains approximately 8000 species grouped into 80 families. They make up one of the most important components in marine ecosystems (Amaral et al. 1994) mainly due to their predominance in soft bottom macrobenthic communities. They can constitute up to $90 \%$ of the total macrobenthic community in terms of number of species and individuals, up to $80 \%$ of biomass, and up to $70 \%$ of secondary production in both shallow waters and deep-sea sediments (e.g., WłodarskaKowalczuk and Pearson 2004; Bluhm et al. 2005; WłodarskaKowalczuk and Kȩdra 2007; Baldrighi et al. 2013; Degen et al. 2015), but they remain an important part of hard bottom communities as well (e.g., in kelp beds [Włodarska-Kowalczuk et al. 2009] or among encrusting fauna on rocks [Kuklinski 2013]). Moreover, they play an important role in ecosystem functioning due to their diverse life habits, feeding, and reproductive strategies (Fauchald and Jumars 1979; Snelgrove

*Correspondence: basia@iopan.gda.pl

Additional Supporting Information may be found in the online version of this article.
1997). Polychaete worms influence sedimentary processes by bioturbation, redistribution, mineralization, and burial of organic matter (e.g., Hutchings 1998; Morata et al. 2013; Kędra et al. 2013; Zaborska et al. 2018). Polychaetes have also been proposed as effective surrogates of marine biodiversity, because they are good indicators of both environmental variability and the species richness and distributional patterns of the whole benthic community (Giangrande et al. 2005; Włodarska-Kowalczuk and Kȩdra 2007).

Body size plays a key role in structuring marine communities and determining their functioning, and currently, an increasing number of community studies include size-based analyses (Robinson et al. 2010; Hua et al. 2013; Górska and Włodarska-Kowalczuk 2017). The assessment of body-size characteristics is a basic task in studies of taxonomy, ecology, evolution, and growth (Costa-Paiva and Paiva 2007). One of the most important aspects of community, population, or individual functioning is production (Clarke and Warwick 1994), which is a function of density, biomass, growth rate, reproduction, and survivorship of a particular population (Tod and Schmid-Araya 2009). Estimation of secondary production allows the assessment of trophic dynamics within a system 
and the evaluation of trophic potential of its components (Mistri et al. 2001). However, the estimations of secondary production usually require data on individual body weight (e.g., Brey 1990). Weighting of every single individual is time consuming, and in the case of the small macrobenthic worms, it requires an expensive, very precise electro balance (Robinson et al. 2010). Wet weight is not a reliable measure (mainly because of preservation or gut content), whereas a direct assessment of dry weight (DW) or ash free DW is destructive for individuals. Moreover, many of the polychaete individuals become fragmented during the standard sample sieving procedures.

Robinson et al. (2010) recommended calculations based on morphometric measurements for estimating individual body weight. In the case of polychaetes, individual biomass can be derived from biovolume, which is calculated using the cone formula based on whole-body length and maximum width. However, most often measuring the body length of all polychaete individuals in a macrobenthic sample collected with standard methods (sediments collected with a grab or corer and sieved on board) is impossible because a high percentage of individuals are damaged during sampling and sample processing (Pardo et al. 2010). Several authors reported that only $30-50 \%$ of all individuals in a sample remained undestroyed (e.g., Desrosiers et al. 1988; Ieno et al. 2000; Omena and Amaral 2001; this study). This fact fuels the search for a method to determine the total length of fragmented individuals using correlations between the total length and the morphometric traits of body parts that remain intact after sampling, e.g., width/length of different chaetigers or segments, length of anterior region, and length/width of prostomium or buccal appendages (e.g., Fauchald 1991; Omena and Amaral 2001; Occhioni et al. 2009). However, there are only a few published reports presenting useful correlations, and these studies are either focused on only one or a few species, e.g., the 15 species (representing four orders: Aphroditoidea, Eunicida, Phyllodocida, and Terebellida) published by Robinson et al. (2010) or the 3 species (representing two orders: Phyllodocida and Sabellida) published by Rosati et al. (2012). Most of the published studies focus on relationships between width and weight (e.g., Speybroeck et al. 2007). However, some authors compiled relationships between total length and selected morphometric features, e.g., Paterson et al. (2006) tested the correlation between total length and width of the first chaetiger and reported significant relationships for six families (Acrocirridae, Cirratulidae, Paraonidae, Sabellidae, Spionidae, and Syllidae). They used the width of the first chaetiger as a surrogate for total length in their polychaete size structure analyses, but the actual regression equations between width of the first chaetiger and total length were not published. Omena and Amaral (2001) tested the linear regression between total length and nine morphometric features (e.g., width, width of second chaetiger, and length of sixth chaetiger), but the study was conducted on only one species-
Laeonereis acuta (Nereididae). Ieno et al. (2000) reported a significant relationship between width of the 10th segment (wS10) and the total length of intact individuals (length = $13.85 \times \mathrm{wS}^{1} 0^{1.49}$ ) for the same species. Heip and Herman (1979) published a regression equation for relationship between total length and wS10 (length $=15.5 \times \mathrm{wS}^{1.41}$ ) for Nereis diversicolor (Nereididae). Costa-Paiva and Paiva (2007) calculated correlations among 16 morphometric features as a size estimator of Eunice (Eunicidae), and all of them presented high correlations (above 0.80), but the best relationships were between size and width of peristomium and length of dorsolateral palps; however, again, the regression equations were not published. Occhioni et al. (2009) showed a significant correlation between the length of the first thoracic chaetiger and the total length of Phragmatopoma caudata (Sabellidae).

In this study, we present a methodology for size assessment in 28 polychaete families. The correlations between the total length and widths of chaetigers (i.e., segments bearing chaete) of the anterior body part were computed based on measurements of 3580 intact individuals collected within a wide range of depths (76-5561 m) from five localities in the Arctic and one in the sub-Arctic. We determine the best total length estimators for each of the 28 families representing the most common and dominant polychaete taxa in Arctic marine sediments. To our knowledge, our assessment is the first to encompass a comprehensive range of polychaete families and is based on materials from different localities and depths. The presented methodology can be useful for a wide variety of studies that require an assessment of size but also biomass, production and other metrics that can be derived from size (see e.g., Brey 2010) in benthic biota.

\section{Materials and methods}

Materials were collected during several sampling campaigns in four Arctic fjords (Hornsund, Kongsfiorden, Isfiorden, and Rijpfiorden), one subarctic fjord (Ullsfiorden), and an Arctic open-water, deep-sea site (Hausgarten, Fram Strait; Fig. 1). Sampling stations were localized at depths ranging from 76 to $5561 \mathrm{~m}$. Materials were collected with the use of various sampling gear: a Van Veen grab (sampling area $0.1 \mathrm{~m}^{2}$ ), a smallbox corer (sampling area $0.0625 \mathrm{~m}^{2}$ ) in coastal/shelf waters, and a giant-box corer (sampling area $0.25 \mathrm{~m}^{2}$ ) at the deep-sea stations and fixed with $4 \%$ formaldehyde solution buffered with seawater. The intact specimens came both from the standard macrobenthic sampling performed in the scope of several projects carried on at the Institute of Oceanology Polish Academy of Sciences (IO PAS) between 2010 and 2015 and from sampling dedicated especially to the purposes of this study. In the first case, the samples were treated on board with a standard procedure-sieved on board through $500 \mu \mathrm{m}$ sieves, fixed, and analyzed (in terms of taxonomic composition) in the laboratory. The extensive search through a large number of such samples archived at the IO PAS resulted in obtaining 


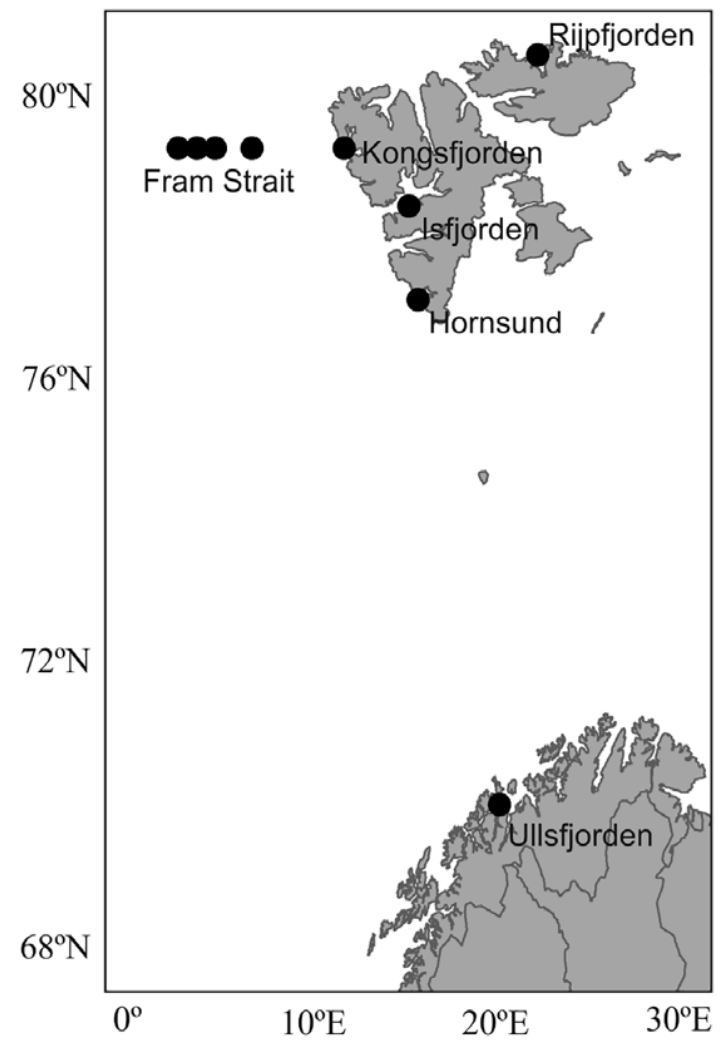

Fig. 1. Map of sampling locations.

unsatisfactory numbers of intact individuals (especially in families Nereididae and Flabelligeridae); therefore, in 2014 and 2015, several samples were collected especially for this purpose. These samples were collected with a small-box corer and fixed on board (without sieving) with a formaldehyde solution in seawater. In the laboratory, the samples were gently washed on $500 \mu \mathrm{m}$ sieves, and only complete individuals were picked and identified to species. The collection of such samples resulted in obtaining 154 individuals of intact polychaete worms.

All individuals used for the present study were identified to the lowest possible taxonomic resolution (species or genus level) based on Chambers (2000), Chambers and Woodham (2003), Fauchald (1977), Holthe (1986), Hartmann-Schroder (1996), and Jirkov (2001). A total of 3580 complete specimens representing 28 families were used in the analyses (Table 1). All these specimens were photographed under a Leica M205C stereomicroscope (with magnification from $5 \mathrm{X}$ to $160 \mathrm{X}$ ) connected to a Leica DFC450 digital camera and measured using the digital image analysis in Leica Application Suite (LAS v.4.0). For each specimen, the width of the first seven chaetigers (segments bearing chaete) and total length (without anal cirri) were measured and expressed in $\mu \mathrm{m}$ (Fig. 2; Supporting Information Figs. S1-S3). Measurements were made on the dorsal or ventral view of specimens. The width of chaetigers did not include parapodia or bristles.
Most polychaete families have the capacity to generate new posterior segments after natural fragmentation caused, e.g., by a predator attack (Bely 2006). During the regeneration process, the newly developed segments can be distinguished from the residual segments by their smaller size and width (sudden drop in width after one segment). After several weeks, these differences may disappear, and the specimens that have undergone regeneration may be not be distinguishable by visual inspection anymore (e.g., Weidhase et al. 2015). Individuals that had distinguishable regenerated segments were not used for further analyses.

A Pearson correlation was used to evaluate the relationships between chaetiger widths and total lengths, and regression equations were obtained that could be used for total length estimations in the groups of specimens representing families, suborders, orders, classes, and the whole polychaete collection (Supporting Information Table S1). The regression equation describing the relationship with the highest (and significant) correlation coefficient was selected for each family, suborder, order, infraclass, subclass, and whole Polychaeta class (Table 2). For families, which slopes of regression in groups of samples representing various genera/species were apparently different (Capitellidae, Cirratulidae, Oweniidae and Trichobranchidae), analysis of covariance (ANCOVA) test was performed to test for differences among regression slopes.

Calculated equations for each family were used for the calculation of $\%$ error using the formula: \% error $=([$ estimated length - measured length]/measured length) $\times 100 \%$. Mean, median, and maximum \% error for each family, order, suborder, infraclass, subclass, and the class Polychaeta were presented (Supporting Information Table S1). Additionally, the mean \% error for each family was calculated using the equation for order (or infraclass) and the class Polychaeta (Supporting Information Table S2).

The presented method of obtaining the total lengths in fragmented polychaetes was applied to materials collected at six sampling stations in west Spitsbergen fjords (as described in Górska and Włodarska-Kowalczuk [2017]). At each station, three replicate samples were collected with the use of a van Veen grab (sampling area $0.1 \mathrm{~m}^{2}$ ), sieved on a $500 \mu \mathrm{m}$ mesh and preserved with a formaldehyde solution in seawater on board. In the laboratory, all animals were encountered and identified to the lowest possible taxonomic level (usually to the species or genus) and measured under a stereomicroscope connected to a camera. For fragmented individuals, the correlations to selected chaetiger widths (Table 2) were used to derive the total-body length. Body dimensions (width and total length) were converted into biovolume and to dry mass using published conversion factors (Brey 2001; Brey et al. 2010). Each individual was classified into $\log _{2}$ size classes based on its DW ( $\mu$ g; from $\geq 2^{x}$ to $<2^{x+1}$, where $x$ is the size class). Biomass and abundance size spectra were constructed for Polychaeta by plotting the sum of biomass or abundance (average from 18 samples) in each size class against the 
Table 1. Information on taxonomic affinities of the specimens measured within the study (numbers of individuals representing particular taxa are given in brackets).

\section{Class: POLYCHAETA (3580) \\ Subclass: Sedentaria (2792) \\ Infraclass: Scolecida (1027) \\ Family: Capitellidae (22): Capitella capitata (13), Heteromastus filiformis (9) \\ Family: Cossuridae (114): Cossura pygodactylata (114) \\ Family: Maldanidae (292): Chirimia biceps (11), Euclymeninae (1), Maldane arctica (1), Maldane sarsi (276), Microclymene acirrata} (3)

Family: Opheliidae (146): Ammotrypanella arctica (22), Ophelina abranchiata (18), Ophelina acuminata (19), Ophelina cylindricaudata (1), Ophelina minima (75), Ophelina modesta (1), Opheliidae non det. (10)

Family: Orbiniidae (241): Leitoscoloplos mammosus (241)

Family: Paraonidae (201): Aricidea spp. (4), Aricidea suecica (1), Levinsenia gracilis (19), Paradoneis eliasoni (1), Paradoneis lyra (26), Paraonides nordica (56), Paraonidae non det. (94)

Family: Scalibregmatidae (11): Asclerocheilus sp. (1), Polyphysia crassa (2), Pseudoscalibregma parvum (3), Scalibregma inflatum (5)

Infraclass: Canalipalpata (1765)

Order: Terebellida (817)

Suborder: Cirratuliformia (306)

Family: Cirratulidae (299): Aphelochaeta spp. (29), Chaetozone jubata (5), Chaetozone setosa (163), Chaetozone spp. (17), Cirratulus caudatus (2), Cirratulus sp. (8), Tharyx spp. (75)

Family: Flabelligeridae (7): Diplocirrus longisetosus (5), Brada villosa (2)

Suborder: Terebellomorpha (511)

Family: Pectinariidae (46): Cistenides granulata (1), Cistenides hyperborea (45)

Family: Ampharetidae (105): Amage auricula (1), Ampharete finmarchica (4), Ampharete borealis (9), Ampharetinae (10), Amphicteis gunneri (23), Amphicteis sundevalli (1), Anobothrus gracilis (5), Anobothrus laubieri (11), Glyphanostomum pallescens (4), Lysippe labiata (30), Melinna cristata (3), Melinna elisabethae (1), Samytha sexcirrata (1), Sosane wireni (2)

Family: Terebellidae (228): Amaeana trilobata (1), Terebellinae (23), Lanassa nordenskioldi (1), Lanassa venusta (6), Laphania boecki (2), Leaena ebranchiata (19), Neoamphitrite groenlandica (1), Polycirrus arcticus (122), Polycirrus spp. (49), Proclea graffi (1), Proclea malmgreni (1), Streblosoma intestinale (2)

Family: Trichobranchidae (132): Terebellides sp. (29), Terebellides stroemii (103)

Order: Spionida (230)

Family: Apistobranchidae (38): Apistobranchus tullbergi (38)

Family: Spionidae (192): Dipolydora quadrilobata (19), Dipolydora sp. (10), Glyphochaeta laudieni (1), Prionospio cirrifera (148), Spio spp. (12), Laonice cirrata (2)
Table 1. (Continued)

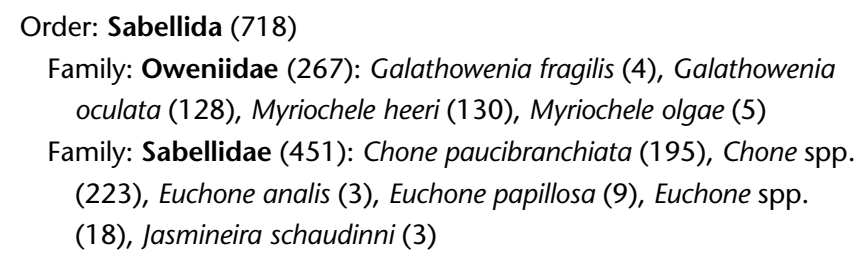

Family: Sphaerodoridae (21): Ephesiella abyssorum (1), Ephesiella peripatus (1), Sphaerodoridium sp. (16), Sphaerodoropsis philippi (3)

$\log _{2}$-transformed size of a class. For more details on these materials and size spectra construction procedures, see Górska and Włodarska-Kowalczuk (2017). The percentages of the biomass and abundance derived only from the intact Polychaeta individuals in the total biomass and abundance of Polychaeta in size classes were calculated.

\section{Assessment}

A total of 3580 intact polychaete specimen belonging to 96 species, 28 families, six orders, two infraclasses, and one subclass were measured. The number of individuals measured per family varied (Table 1), and the low number of individuals in some families reflected the rareness of the occurrence in 

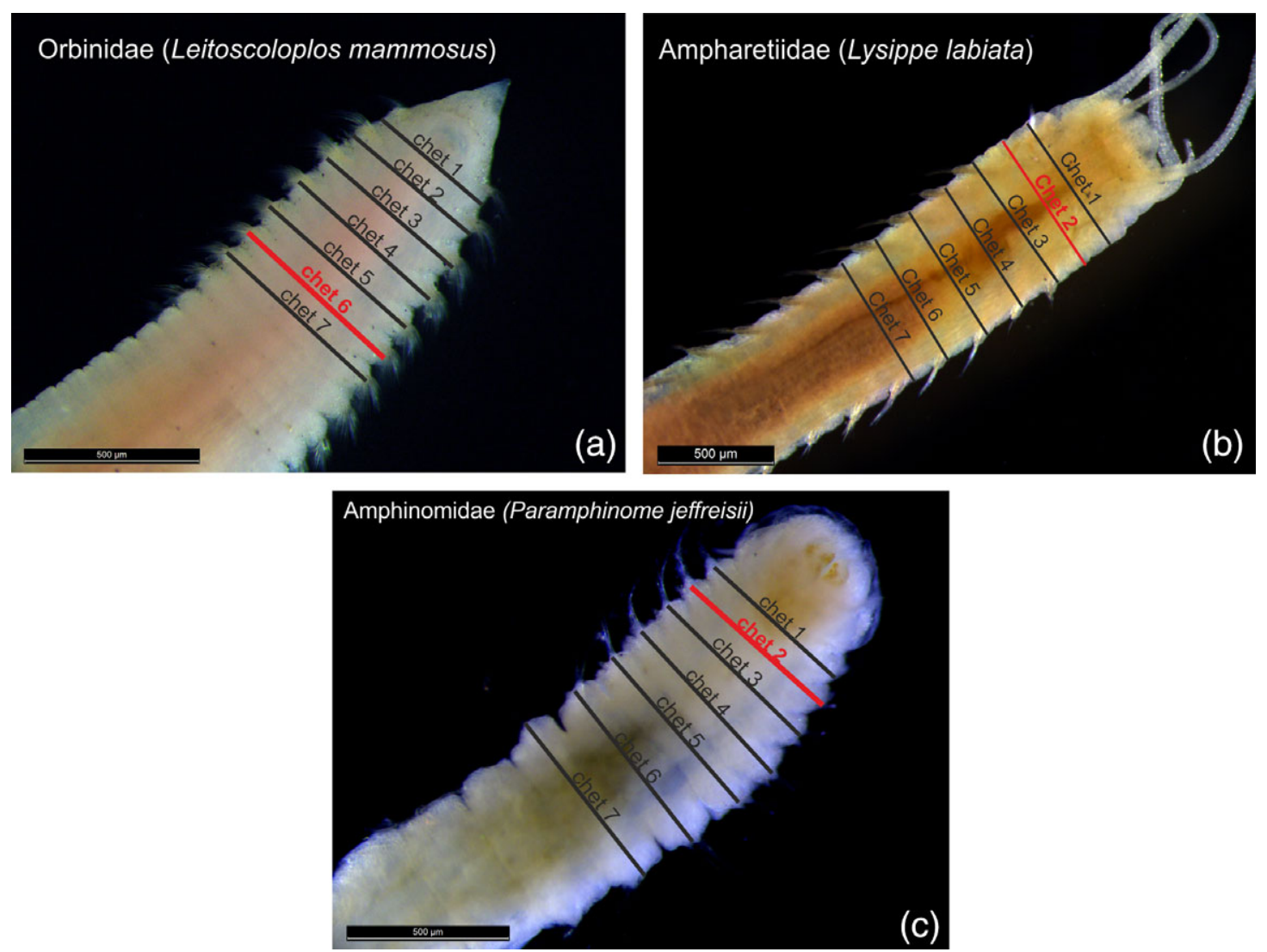

Fig. 2. Measurements of first seven chaetigers of exemplary individuals belonging to three families (a) Orbinidae (infraclass Scolecida), (b) Ampharetiidae (infraclass Canalipalpta), and (c) Amphinomidae (subclass Errantia).

collected samples (e.g., Flabelligeridae, Onuphidae, and Dorvilleidae) or the extreme body fragility leading to fragmentation, even after careful sample treatment (e.g., Lumbrineridae and Cirratulidae). Taxonomic classification was based on the World Register of Marine Species (WORMS Editorial Board 2018).

All correlations between widths of chaetigers and total lengths were significant $(p<0.05$; Supporting Information Table S1), in addition to correlations between chaetigers 1-7 and total length for Heteromastus filiformis (Supporting Information Table S1). Most correlations were significant at levels $p<0.0001$, and only in the families Sphaerodoridae, Onuphidae, Dorvilleidae, and Capitellidae was $p$ higher than 0.0001 but lower than 0.05 . Pearson correlation coefficients ranged from 0.29 (order Sabellida) to 0.99 (family Flabelligeridae). Coefficients of determination ranged from 0.09 (Sabellida) to 0.98 (Flabelligeridae). All correlations were based on measurements of at least 10 specimens, other than that for the family Flabelligeridae (Supporting Information Table S1). Correlations for Flabelligeridae were based only on seven specimens, but still, the strongest correlation was very high $(r>0.98)$. Because of the low number of intact individuals of Nereididae found in the samples (only three specimens), the correlation was not calculated. Within the families
Capitellidae, Cirratulidae, Oweniidae, and Trichobranchidae, the slopes of regression in groups of samples representing various genera/species were significantly different (ANCOVA: $F_{\text {Capitellidae }}(19,1)=7.69, p<0.05 ; \quad F_{\text {Cirratulidae }}(295,1)=18.2$, $p<0.001 ; \mathrm{F}_{\text {Oweniidae }}(236,1)=148.5, p<0.001 ; F_{\text {Trichobranchidae }}$ $(128,1)=5.0, p<0.05$; Supporting Information Figs. S4-S6); therefore, additional correlations and regression equations were calculated for these genera or species (Supporting Information Fig. S7). The mean \% error calculated for the length derived from presented equations varied between 8.3 (Pectinariidae) and 117.0 (subclass Errantia; Supporting Information Table S1).

The 53 best-fitted regression equations were selected for the studied groups (families, suborders, orders, infraclasses, subclass, class, and selected species/genera; Table 2; Supporting Information Figs. S4-S7). Among them, the coefficients of determination varied between 0.17 and 0.98 . The width of chaetiger 1 was best correlated with the total length in most taxa (29 best-fitted regression equations). For all polychaete data combined, chaetiger 7 was best correlated to the total length $(r=0.60$; Table 2$)$. At the level of subclass, chaetiger 7 was best correlated to total length for Sedentaria, while chaetiger 1 was best for Errantia (Fig. 3). The mean \% error calculated from length estimations derived from equations for 
Table 2. Best-fitted regression equations.

\begin{tabular}{|c|c|c|c|c|c|c|c|c|}
\hline & Equation & Chaet & $p$ & $r^{2}$ & $N$ & Mean \%e & Median \%e & Max \%e \\
\hline Polychaeta (class) & $L=4857.1+9.3 \times$ chaet & Chaet 7 & $<0.0001$ & 0.36 & 3580 & 82.5 & 49.8 & 2035.8 \\
\hline Sedentaria (subclass) & $L=5538.3+8.9 \times$ chaet & Chaet 7 & $<0.0001$ & 0.38 & 2787 & 69.0 & 49.1 & 472.4 \\
\hline Scolecida (infraclass) & $L=-888.7+32.7 \times$ chaet & Chaet 1 & $<0.0001$ & 0.84 & 1026 & 34.2 & 23.3 & 509.7 \\
\hline Capitellidae & $L=5527.7+12.2 \times$ chaet & Chaet 1 & $<0.001$ & 0.43 & 22 & 22.6 & 21.3 & 102.7 \\
\hline C. capitata & $L=2476.6+16.7 \times$ chaet & Chaet 1 & $<0.001$ & 0.71 & 13 & 16.8 & 14.2 & 56.2 \\
\hline H. filiformis & $L=1792.6+29.2 \times$ chaet & Chaet 1 & 0.11 & 0.32 & 9 & 17.2 & 12.7 & 46.8 \\
\hline Cossuridae & $L=-905.9+20.7 \times$ chaet & Chaet 7 & $<0.0001$ & 0.45 & 114 & 19.3 & 14.5 & 101.6 \\
\hline Maldanidae & $L=-347.1+31.7 \times$ chaet & Chaet 3 & $<0.0001$ & 0.92 & 292 & 17.3 & 14.3 & 68.8 \\
\hline Opheliidae & $L=-2752.4+27.2 \times$ chaet & Chaet 4 & $<0.0001$ & 0.92 & 146 & 26.5 & 20.7 & 95.4 \\
\hline Orbinidae & $L=-3544.0+24.1 \times$ chaet & Chaet 6 & $<0.0001$ & 0.71 & 241 & 24.5 & 20.7 & 100.6 \\
\hline Paraonidae & $L=-5118.5+53.8 \times$ chaet & Chaet 3 & $<0.0001$ & 0.61 & 201 & 31.9 & 26.1 & 151.9 \\
\hline Scalibregmidae & $L=-1351.2+16.7 \times$ chaet & Chaet 1 & $<0.0001$ & 0.91 & 11 & 41.4 & 23.9 & 182.6 \\
\hline Canalipalpata (infraclass) & $L=5710.9+7.3 \times$ chaet & Chaet 7 & $<0.0001$ & 0.41 & 1761 & 72.1 & 51.6 & 462.0 \\
\hline Terebellida (order) & $L=5804.1+6.8 \times$ chaet & Chaet 7 & $<0.0001$ & 0.62 & 813 & 44.5 & 29.7 & 348.6 \\
\hline Cirratuliformia (suborder) & $L=-895.4+29.7 \times$ chaet & Chaet 1 & $<0.0001$ & 0.51 & 304 & 35.6 & 23.8 & 423.9 \\
\hline Cirratulidae & $L=-1465.3+31.7 \times$ chaet & Chaet 1 & $<0.0001$ & 0.57 & 299 & 32.0 & 25.1 & 195.4 \\
\hline Aphelochaeta and Tharyx & $L=-4147.2+50.2 \times$ chaet & Chaet 1 & $<0.0001$ & 0.66 & 104 & 33.4 & 22.7 & 284.5 \\
\hline Chaetozone and Cirratulus & $L=-4712.3+36.2 \times$ chaet & Chaet 1 & $<0.0001$ & 0.79 & 195 & 32.2 & 21.6 & 148.7 \\
\hline Flabelligeridae & $L=1523.0+4.0 \times$ chaet & Chaet 2 & $<0.0001$ & 0.98 & 7 & 20.1 & 8.5 & 61.0 \\
\hline Terebellomorpha (suborder) & $L=3382.6+8.3 \times$ chaet & Chaet 7 & $<0.0001$ & 0.70 & 511 & 37.5 & 28.7 & 206.0 \\
\hline Pectinariidae & $L=1422.4+5.3 \times$ chaet & Chaet 1 & $<0.0001$ & 0.71 & 46 & 8.3 & 7.2 & 27.8 \\
\hline Ampharetiidae & $L=2433.7+7.9 \times$ chaet & Chaet 2 & $<0.0001$ & 0.91 & 105 & 32.1 & 25.3 & 114.1 \\
\hline Terebellidae & $L=-540.2+14.5 \times$ chaet & Chaet 1 & $<0.0001$ & 0.88 & 228 & 28.0 & 20.0 & 216.6 \\
\hline Trichobranchidae & $L=3837.6+12.4 \times$ chaet & Chaet 1 & $<0.0001$ & 0.83 & 132 & 25.6 & 14.8 & 147.3 \\
\hline Terebellides sp. & $L=-100.1+24.8 \times$ chaet & Chaet 3 & $<0.0001$ & 0.72 & 29 & 15.8 & 11.0 & 48.8 \\
\hline Terebellides stroemii & $L=1809.4+13.5 \times$ chaet & Chaet 1 & $<0.0001$ & 0.84 & 103 & 21.9 & 14.6 & 91.1 \\
\hline Spionida (order) & $L=-8699.7+47.5 \times$ chaet & Chaet 5 & $<0.0001$ & 0.74 & 230 & 59.3 & 27.4 & 362.1 \\
\hline Apistobranchidae & $L=-3843.4+21.5 \times$ chaet & Chaet 3 & $<0.0001$ & 0.65 & 38 & 25.6 & 22.4 & 90.3 \\
\hline Spionidae & $L=-10,697.2+75.1 \times$ chaet & Chaet 1 & $<0.0001$ & 0.84 & 192 & 35.9 & 14.5 & 286.1 \\
\hline Sabellida (order) & $L=1593.5+16.9 \times$ chaet & Chaet 1 & $<0.0001$ & 0.17 & 718 & 71.3 & 63.2 & 303.4 \\
\hline Oweniidae & $L=4733.0+22.9 \times$ chaet & Chaet 1 & $<0.0001$ & 0.27 & 267 & 57.7 & 40.8 & 339.5 \\
\hline Myriochele sp. & $L=-431.0+26.4 \times$ chaet & Chaet 1 & $<0.0001$ & 0.67 & 135 & 32.0 & 21.9 & 156.7 \\
\hline Galathowenia sp. & $L=-3751.6+74.5 \times$ chaet & Chaet 1 & $<0.0001$ & 0.77 & 132 & 22.9 & 13.5 & 272.0 \\
\hline Sabellidae & $L=-1183.4+16.5 \times$ chaet & Chaet 1 & $<0.0001$ & 0.65 & 451 & 24.2 & 16.5 & 178.6 \\
\hline Errantia (subclass) & $L=-210.3+20.4 \times$ chaet & Chaet 1 & $<0.0001$ & 0.56 & 788 & 87.9 & 50.8 & 1317.9 \\
\hline Amphinomida (order) & $L=-2415.5+12.8 \times$ chaet & Chaet 2 & $<0.0001$ & 0.55 & 229 & 32.1 & 27.2 & 115.3 \\
\hline Amphinomidae & $L=-2415.5+12.8 \times$ chaet & Chaet 2 & $<0.0001$ & 0.55 & 229 & 32.1 & 27.2 & 115.3 \\
\hline Eunicida (order) & $L=324.0+25.0 \times$ chaet & Chaet 1 & $<0.0001$ & 0.72 & 201 & 45.8 & 29.6 & 315.4 \\
\hline Dorvilleidae & $L=-3937.0+22.7 \times$ chaet & Chaet 1 & 0.001 & 0.62 & 14 & 14.6 & 12.4 & 48.5 \\
\hline Lumbrineridae & $L=-5861.6+41.8 \times$ chaet & Chaet 4 & $<0.0001$ & 0.83 & 176 & 19.9 & 15.0 & 119.5 \\
\hline Onuphidae & $L=-7525.3+24.8 \times$ chaet & Chaet 1 & $<0.0001$ & 0.93 & 11 & 21.3 & 14.2 & 60.3 \\
\hline Phyllodocida (order) & $L=1822.2+17.5 \times$ chaet & Chaet 1 & $<0.0001$ & 0.53 & 358 & 88.1 & 43.6 & 1661.9 \\
\hline Aphroditiformia (suborder) & $L=-1388.4+11.2 \times$ chaet & Chaet 2 & $<0.0001$ & 0.95 & 56 & 26.3 & 15.8 & 170.5 \\
\hline Pholoidae & $L=378.2+7.10 \times$ chaet & Chaet 1 & $<0.0001$ & 0.51 & 44 & 29.6 & 23.2 & 133.8 \\
\hline Polynoidae & $L=-2178.6+11.1 \times$ chaet & Chaet 3 & $<0.0001$ & 0.95 & 12 & 14.0 & 10.8 & 30.8 \\
\hline Nereidiformia (suborder) & $L=2300.3+11.2 \times$ chaet & Chaet 7 & $<0.0001$ & 0.68 & 91 & 50.0 & 29.2 & 274.7 \\
\hline Nereididae & - & - & - & - & - & - & - & - \\
\hline Syllidae & $L=-3061.1+31.8 \times$ chaet & Chaet 1 & $<0.0001$ & 0.53 & 88 & 47.6 & 30.4 & 332.2 \\
\hline Phyllodociformia (suborder) & $L=-5023.32+46.2 \times$ chaet & Chaet 1 & $<0.0001$ & 0.63 & 172 & 63.0 & 35.9 & 1872.5 \\
\hline
\end{tabular}


Table 2. (Continued)

\begin{tabular}{|c|c|c|c|c|c|c|c|c|}
\hline & Equation & Chaet & $p$ & $r^{2}$ & $N$ & Mean \%e & Median \%e & Max \%e \\
\hline Phyllodocidae & $L=-5023.32+46.2 \times$ chaet & Chaet 1 & $<0.0001$ & 0.63 & 172 & 63.0 & 35.9 & 1872.5 \\
\hline Nephtyidae & $L=-2934.0+27.6 \times$ chaet & Chaet 3 & $<0.0001$ & 0.86 & 18 & 40.5 & 25.8 & 180.7 \\
\hline Sphaerodoridae & $L=695.4+2.7 \times$ chaet & Chaet 7 & 0.0002 & 0.52 & 21 & 35.6 & 37.3 & 72.5 \\
\hline
\end{tabular}

chaet, width of selected chaetiger $[\mu \mathrm{m}] ; L$, total length $[\mu \mathrm{m}]$; max \%e, maximum percentage error; mean \%e, mean percentage error; median \%e, median percentage error; $N$, number of individuals; $p$, significance level; $r^{2}$, coefficient of determination.

orders was $87 \%$ (average), for class Polychaeta was $102 \%$ (average), whereas that based on equations for family was $29 \%$ (Supporting Information Table S2).

Polychaetes collected at six stations in Kongsfjorden and Hornsund belonged to 18 size classes (from $0.125 \mu \mathrm{g}$ to $131 \mathrm{mg}$; Fig. 4a). The percentage contribution of complete individuals in Polychaeta biomass and abundance in size class varied between $0 \%$ and $43 \%$, i.e., from $57 \%$ to $100 \%$ of the information could be obtained only with use of the method described above (Fig. 4a). The highest percentage contribution of intact polychaetes was noted in classes 12-13 (4-16 mg; more than $30 \%$ in terms of polychaete biomass and abundance) that were dominated by Maldanidae, Trichobranchidae, and Pectinaridae. Only in the families Opheliidae and Serpulidae were all collected individuals complete, but these two families were also represented by very low numbers of individuals (from 2 to 4). High contributions of intact individuals were observed in the tube-dwelling families Pectinaridae, Sabellidae, and Trichobranchidae $(>43 \%$ of abundance; Fig. 4b). Very low contributions of intact individuals were observed in the most abundant families: Cirratulidae (12 from a total of 2646 collected individuals, intact specimens represented $0.4 \%$ of Cirratulidae biomass) and Lumbrineridae ( 1 from a total of 1224 individuals, $0.1 \%$ of biomass; Supporting Information Table S3).

\section{Discussion}

The presented method of the total length assessment based on morphological correlations to other morphometric features may have broad application in areas such as benthic ecology and population dynamics studies. Several studies showed the significant relationships between the Polychaeta body length and production (e.g., Heip and Herman 1979; Martin and Bastida 2006), fecundity (Cassai and Prevedelli 1998; Rettob 2012), or biomass (e.g., Arias and Drake 1994; Abrantes et al. 1999). Often, the direct weighting of animals needs to be avoided, because it is destructive for specimens or individuals are too small (Basset and Sabetta 2007), and the relationships between the total length and weight are useful. Another difficulty specific to Polychaeta is the fact that the worms are often broken during standard sample processing (on-board sieving; Omena and Amaral 2001), and thus, either the length or the individual biomass cannot be directly obtained.
In the present study, significant regression equations between the total lengths and the widths of the thoracic chaetigers have been found for 28 families and six orders of the class Polychaeta. All correlations between widths of the first seven chaetigers and total length were significant (except those for $H$. filiformis; however, this species was represented by only nine specimens), which corroborates the notion of the strong potential in applications of morphometric relationships (widths explaining from 0.09 to 0.98 of the variability in total lengths). In most cases, the shapes of relationships between the chaetiger widths and total lengths were similar among the different species/genera within a family. This was not valid for families Oweniidae, Capitellidae, Trichobranchidae, and Cirratulidae, where the slopes of the regressions evidently varied among the different species and/or genera. The species representing these families in our materials were of clearly variable body forms (as described below) and application of the regression formulae constructed at a family level for a species not covered in our materials requires careful examination whether it represents the similar morphological type. In family Trichobranchidae (Supporting Information Fig. S7), Terebellides sp. collected in Fram Strait was much smaller (up to $1 \mathrm{~mm}$ of width and $24 \mathrm{~mm}$ of total length) than $T$. stroemi collected in the shelf area (up to $3.5 \mathrm{~mm}$ of width and $45 \mathrm{~mm}$ of total length), and the slopes of relationships in these two groups of specimens differed, suggesting different taxonomical affinities. In the Oweniidae, relationships in Galathowenia were quite different from those in Myriochele or Owenia. Indeed, G. fragilis and G. oculata are much thinner (mean width : length ratio of 0.02 ) than the representatives of the other two genera (mean width : length ratio of 0.05). In addition, in cirratulids, Aphelochaeta and Tharyx seem to be thinner (mean width : length ratio of 0.04 ) than the other genera (mean width : length ratio of 0.05), whereas in the Capitellidae, $H$. filiformis was much smaller and thinner (mean width : length ratio of 0.03) than measured individuals of Capitella capitata (mean width : length ratio of 0.05). It must be noted that the relationships obtained for the whole families are significant (with correlation coefficient from 0.49 [Oweniidae] to 0.91 [Trichobranchidae]) and can be used, but when the taxonomic identity of a specimen is available, we recommend using separate equations for these genera and/or species rather than the one for the whole family.

The present study was conducted on materials collected and preserved according to standard procedures of the 

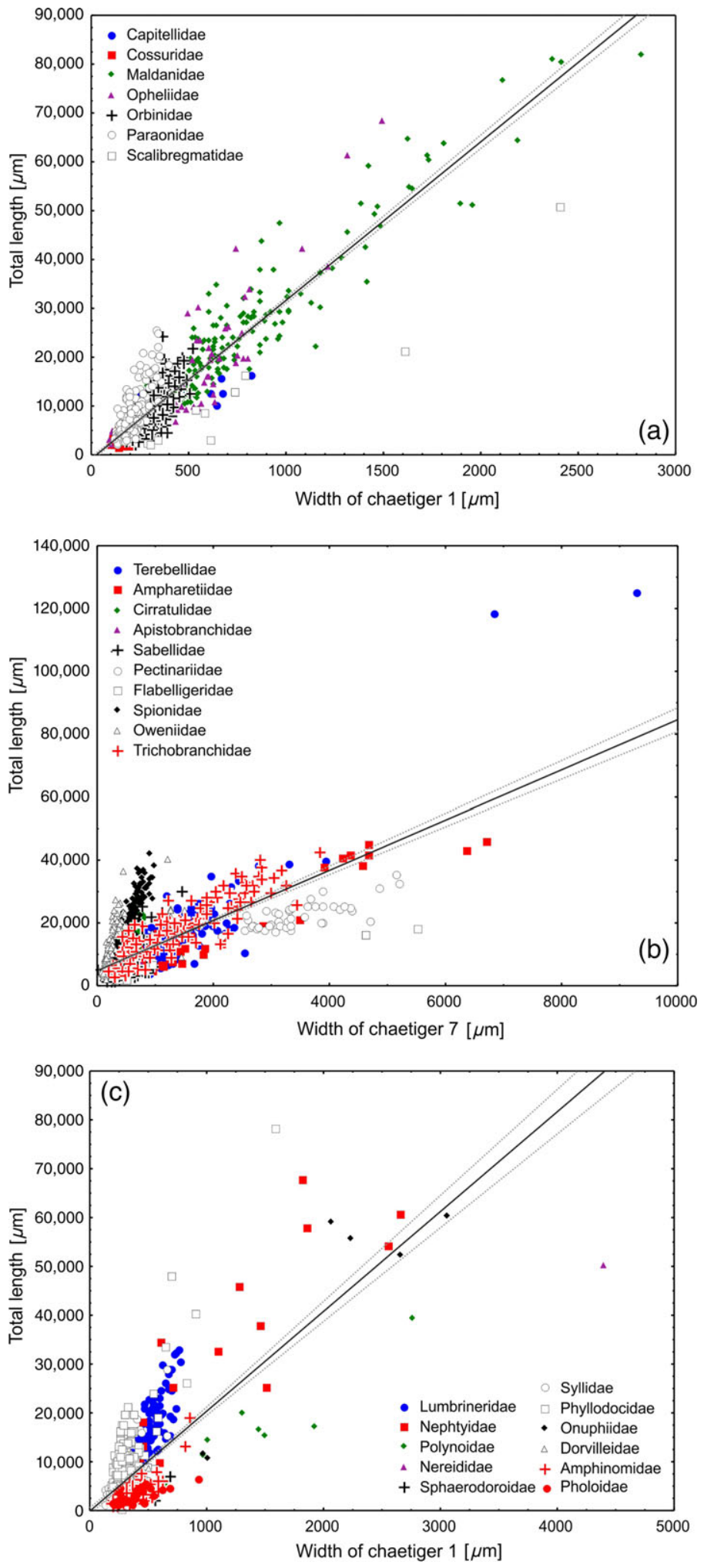

Fig. 3. Relationship between total length $[\mu \mathrm{m}]$ and width of selected chaetiger $[\mu \mathrm{m}]$ for polychaete infraclasses: (a) Sedentaria, (b) Palpata, and subclass (c) Errantia. Regression lines with $0.95 \mathrm{Cl}$ are presented. treatment of benthic ecological samples, including fixation in formalin directly after on-board sieving. In taxonomic studies, the worms for morphometric measurements are often anesthetized prior to fixation, as the fixation can cause muscular contractions and deformations and mask the in vivo animal morphology (Oliveira et al. 2010). However, the anesthetization is also not neutral and can distort morphological features, e.g., due to over-relaxation (Costa-Paiva and Paiva 2007), and it requires additional time for sample preparation (time of relaxation varies from minutes to hours, different chemicals are recommended for different families; Costa-Paiva and Paiva 2007). Ideally any biometrical measurement and biomass estimation should be based on fresh, unpreserved material. In the ecological field studies of marine communities, the immediate sorting and subsequent processing of sampled material are almost impossible; thus, biometrical and biomass parameters are mostly determined from preserved organisms and are obviously affected by the preservation effects (e.g., Leuven et al. 1985; Hjörleifsson and Klein-MacPhee 1992; Gaston et al. 1996; Kapiris et al. 1997; Wetzel et al. 2005). However, both Gaston et al. (1996) and Wetzel et al. (2005), who examined the effects of ethanol and formalin fixation on biomass estimates, claimed that the effects of the preservative were minor in comparison to potential errors due to gut contents or fragmentation of specimens during handling. These sources of errors are omitted when the biomass is estimated from dimensions, as proposed in the methodology in the present article.

In materials collected in Kongsfjorden and Hornsund, the groups with the highest percentage of intact specimens among those collected were the Pectinariidae $(97.6 \%)$, Trichobranchidae (43.7\%), and Sabellidae (45.3\%; Fig. 4b). Worms belonging to these families are characterized by short bodies with less than 100 segments (Pectinaridae $<20$ segments, Trichobranchidae $\sim 60$ segments, Sabellidae $<100$ segments) and dwell in tubes, which protect their bodies against mechanical damage. The biggest problem is damaged individuals - the lowest percentages of intact specimens were observed in the Capitellidae $(0.0 \%)$, Cirratulidae $(0.5 \%)$, Lumbrineridae $(0.1 \%)$, Orbiniidae $(0.2 \%)$, and Cossuridae (0.3\%; Fig. 4b). Individuals belonging to those families are characterized by a long, thin body with numerous (from 80 in Cossuridae up to several hundred in Orbiniidae) segments. Moreover, they do not build any protective structures such as tubes. Regarding the Capitellidae, also Pardo et al. (2010), who worked on C. capitata, which are often numerous and dominant in soft bottom communities, stressed that most individuals of that species in their samples were fragmented. However, the thoracic region was almost always intact, which is why they recommended using length of chaetiger 5 or the area of chaetiger 7 as size estimators. In our study, the width of chaetiger 7 was the characteristic best correlated with the total length of $C$. capitata.

Regarding the size classes, the lowest percentage of damaged individuals was noted in classes 12-13 (4-16 mg DW), which were dominated by individuals of tubiculous, short, and thick worms of the Maldanidae, Trichobranchidae, and Pectrinaridae. 

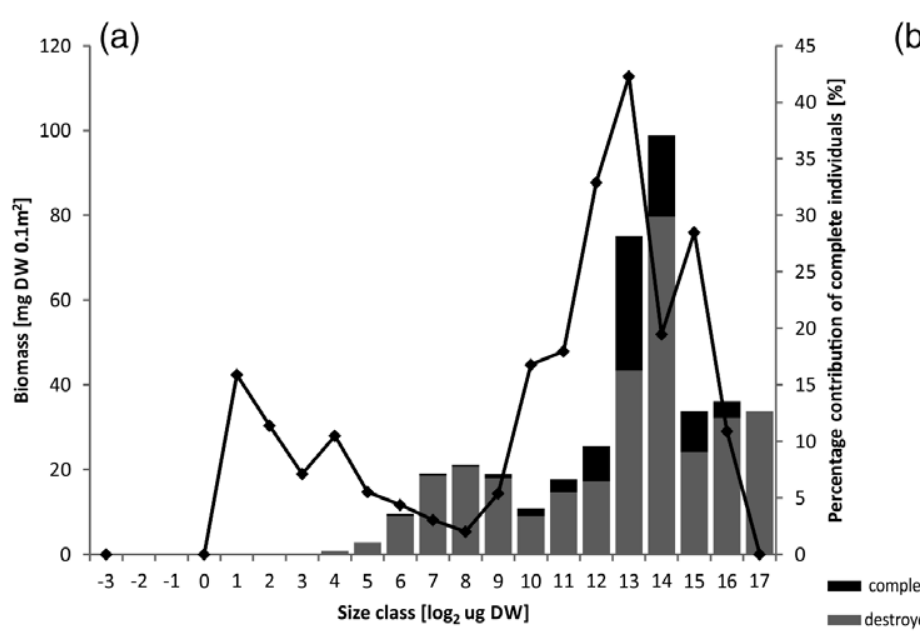

(b)
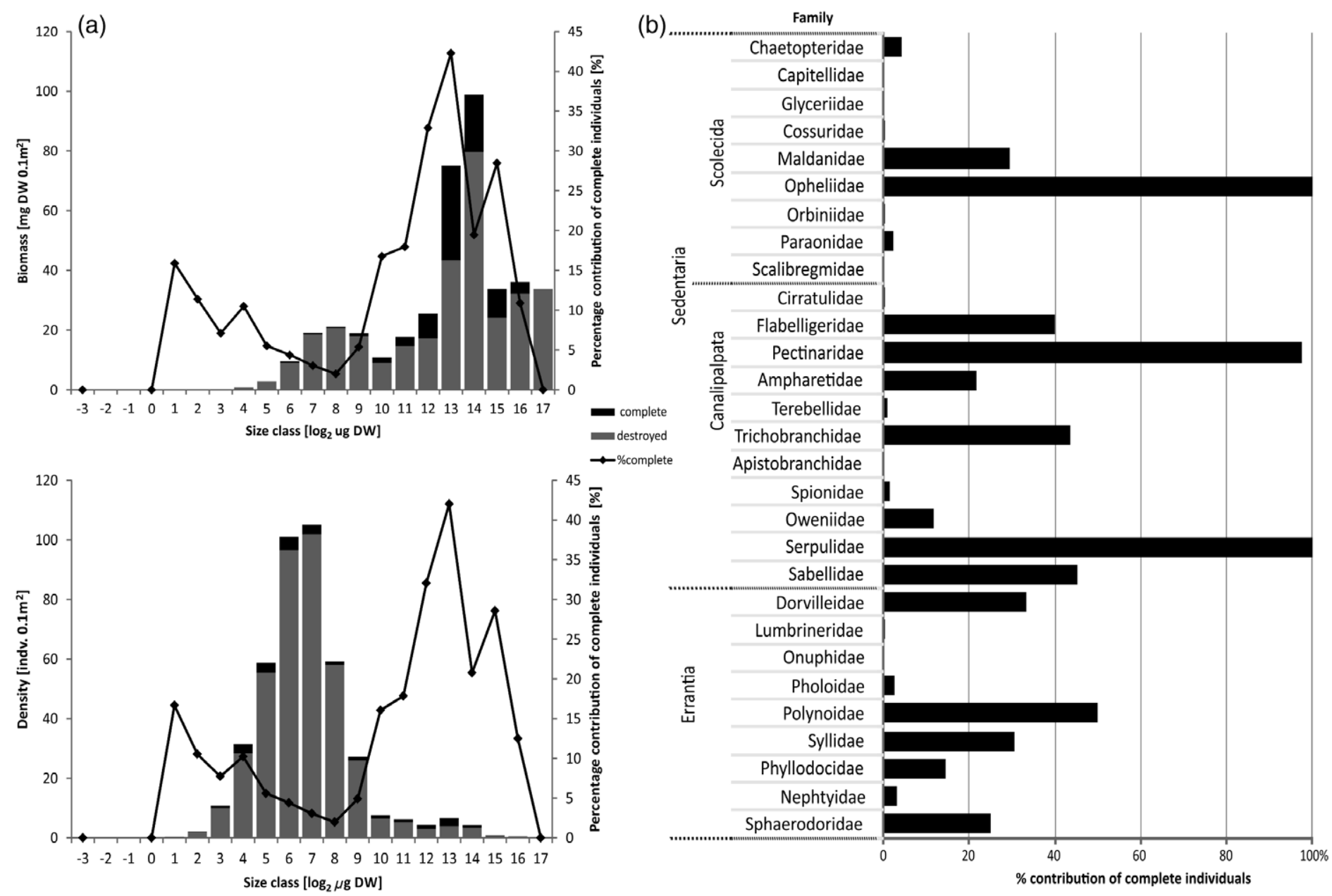

Fig. 4. Polychaeta biomass and density size spectra in Arctic fjords (average of 18 replicate samples) collected at six stations in two fjords (a) and percentage contribution of intact specimens from families found in Arctic fjords (b). The contribution of individuals that were fragmented (and so their dimensions and biomass needed to be estimated with use of the method described in this study) to the total biomass or abundance in a given size class is indicated in the gray part of the respective bar. The percentage of complete individuals of Polychaeta in each size class is indicated by a dot.

In most size classes, intact individuals constituted less than $15 \%$ of polychaetes (in terms of biomass and density), i.e., the size of $85 \%$ of polychaetes in most size classes could only be obtained using correlations between the width of chaetigers and total length. This example shows how severe underestimations of the total benthic biomass can result from neglecting the fragmented polychaetes in a standard macrobenthic study.

The problem of fragmentation of polychaetes in benthic samples has been previously reported, both in standard ecological surveys (Arias and Drake 1994; Paterson et al. 2006) and in size-based studies (e.g., Queirós et al. 2006; Basset and Sabetta 2007; Basset et al. 2012). Several approaches to overcome this problem were proposed, e.g., using body width to calculate the DW (Arias and Drake 1994) or measuring only individuals with at least one third or two thirds of the whole body undestroyed (Queirós et al. [2006] or Basset et al. [2012], respectively). Some authors were resigned to use ecologically meaningful units of animal size (as biovolume or biomass) and instead analyzed the size spectra based on, e.g., the width of the first chaetiger as a proxy of the size (Paterson et al. 2006). However, these approaches are not satisfactorymeasuring only a part of the sampled individuals can lead to huge underestimations of the total community biomass; additionally, the criteria of "at least 30\% of the body undamaged" can be difficult to apply. Relying on proxies such as chaetiger width in a size spectra assessment does not allow the study of the partitioning of the biomass, productivity, or respiration among the size classes and the interpretation of the results in terms of community functioning.

\section{Recommendations}

Equations of the relationship between the width of the selected chaetiger and total length presented in the article allow the estimation of total length of fragmented polychaetes from 28 families and six orders that are common in the North 
Atlantic. Presented method is based on a material collected in a wide range of geographic localities (from $69^{\circ} \mathrm{N}$ to $80^{\circ} \mathrm{N}$ ) and a wide range of sampling depths (70 to $5561 \mathrm{~m}$ ), no differences in the studied morphometric relationships were detected among localities within this wide sampling region. However, applicability of the equations listed in this article in other geographical regions may require testing the equations based on undamaged individuals and, if necessary, constructing a set of regionally specific equations following the presented methodology

We recommend using the best-fitted chaetiger width for each family; however, to facilitate the analyses, one can also use the first chaetiger width for all families (having in mind the increased error, as specified in Supporting Information Table S1). We also recommended using relationships specific for family; however, for wider application of presented method, for families not included in our studies, the relationships assessed at order or class could also be used (provided the error associated with the analyses at this level of taxonomic resolution can be accepted).

With both the total length and width, the assessment of biomass, and thereafter, productivity, respiration, and carbon demand are possible using the models of productivity-the Artificial Neural Network model (Brey 2012) and procedures for the calculation of carbon assimilation (Klages et al. 2004). Assessments of individual biovolume and biomass are inevitable if we are to study the benthic size spectra. The application of the presented method should be useful in a variety of studies that require individual length or biomass assessments and focus, e.g., on morphometry, population dynamics, benthic biomass size spectra, and secondary production, and it should be useful in obtaining precise estimates of the total biomass in macrobenthic samples.

\section{References}

Abrantes, A., F. Pinto, and M. H. Moreira. 1999. Ecology of the polychaete Nereis diversicolor in the Canal de Mira (Ria de Aveiro, Portugal): Population dynamics, production and oogenic cycle. Acta Oecol. 20: 267-283. doi:10.1016/ S1146-609X(99)00139-3

Amaral, A. C. Z., E. F. Nonato, and M. A. V. Petti. 1994. Contribution of the polychaetous annelids to the diet of some Brazilian fishes. Memoir. Mus. Natl. Hist. 162: 331-337.

Arias, A., and P. Drake. 1994. Structure and production of the benthic macroinvertebrate community in a shallow lagoon in the Bay of Cadiz. Mar. Ecol. Prog. Ser. 115: 151-167. doi:10.3354/meps115151

Baldrighi, E., S. Aliani, A. Conversi, M. Lavaleye, M. Borghini, and E. Manini. 2013. From microbes to macrofauna: An integrated study of deep benthic communities and their response to environmental variables along the Malta Escarpment (Ionian Sea). Sci. Mar. o: 625-639. doi:10.3989/ scimar.03811.03B
Basset, A., and L. Sabetta. 2007. Body-size patterns, p. 483489. In S.E. Jorgensen and B.D. Fath [eds.], Systems Ecology, Encyclopedia of Ecology, Elsevier.

Basset, A., and others. 2012. A benthic macroinvertebrate size spectra index for implementing the water framework directive in coastal lagoons in Mediterranean and Black Sea ecoregions. Ecol. Indic. 12: 72-83. doi:10.1016/j.ecolind.2011.06.012

Bely, A. E. 2006. Distribution of segment regeneration ability in the Annelida. Integr. Comp. Biol. 46: 508-518. doi: 10.1093/icb/icj051

Bluhm, B. A., I. R. MacDonald, C. Debenham, and K. Iken. 2005. Macro- and megabenthic communities in the high Arctic Canada Basin: Initial findings. Polar Biol. 28: 218-231. doi:10.1007/s00300-004-0675-4

Brey, T. 1990. Confidence limits for secondary production estimates: Application of the bootstrap to the increment summation method. Mar. Biol. 106: 503-508. doi:10.1007/ BF01344330

Brey, T. 2001. Population dynamics in benthic invertebrates. A virtual handbook. Version 01.2. [Accessed 2018 December 01]. Available from http://www.thomas-de/science/

Brey, T. 2010. An empirical model for estimating aquatic invertebrate respiration. Methods Ecol. Evol. 1: 92-101. doi:10.1111/j.2041-210X.2009.00008.x

Brey, T. 2012. A multi-parameter artificial neural network model to estimate macrobenthic invertebrate productivity and production. Limnol. Oceanogr. Methods 10: 581-589. doi:10.4319/lom.2012.10.581

Brey, T., C. Müller-Wiegmann, Z. M. C. Zittier, and W. Hagen. 2010. Body composition in aquatic organisms-a global data bank of relationships between mass, elemental composition and energy content. J. Sea Res. 64: 334-340. doi: 10.1016/j.seares.2010.05.002

Cassai, C., and D. Prevedelli. 1998. Reproductive effort, fecundity and energy allocation in Marphysa sanguinea (Polychaeta: Eunicidae). Invertebr. Reprod. Dev. 34: 133-138. doi:10.1080/07924259.1998.9652645

Chambers, S. J. 2000. A redescription of Chaetozone setosa Malmgren, 1867 including a definition of the genus, and a description of a new species of Chaetozone (Polychaeta: Cirratulidae) from the Northeast Atlantic. Bull. Mar. Sci. 67: 587-596.

Chambers, S. J., and A. Woodham. 2003. A new species of Chaetozone (Polychaeta: Cirratulidae) from deep water in the Northeast Atlantic, with comments on the diversity of the genus in cold northern waters. Hydrobiologia 496: 41-48. doi:10.1023/A:1026116008735

Clarke, K. R., and R. M. Warwick. 1994. Change in marine communities: An approach to statistical analysis and interpretation. Plymouth Marine Laboratory.

Costa-Paiva, E. M., and P. C. Paiva. 2007. A morphometric analysis of Eunice Cuvier (Annelida, Polychaeta) species. Rev. Bras. Zool. 24: 353-358. doi:10.1590/ S0101-81752007000200013 
Degen, R., A. Vedenin, M. Gusky, A. Boetius, and T. Brey. 2015. Patterns and trends of macrobenthic abundance, biomass and production in the deep Arctic Ocean. Polar Res. 34: 24008. doi:10.3402/polar.v34.24008

Desrosiers, G., B. Vincent, C. Retiere, and L. Boucher. 1988. Compairison de critères utilisables pour l'étude de la structure des populations du polychète Nereis virens (Sars). Can. J. Zool. 66: 1454-1459. doi:10.1139/z88-212

Fauchald, K. 1977. The Polychaete worms. Definitions and keys to the orders, families and genera. Sci. Ser. 28: 188-111. doi:10.3354/dao063107

Fauchald, K. 1991. A morphometric study of eunicid polychaetes from Belize, Western Caribbean Sea. Ophelia 5: 47-53.

Fauchald, K., and P. Jumars. 1979. The diet of worms: A studies of Polychaete feeding gilds. Oceanogr. Mar. Biol. Annu. Rev. 17: 193-284. doi:10.1017/CBO9781107415324.004

Gaston, G., J. Bartlett, A. McAllister, and R. Heard. 1996. Biomass variations of estuarine macrobenthos preserved in ethanol and formalin. Estuaries 19: 674-679. doi: $10.2307 / 1352527$

Giangrande, A., M. Licciano, and L. Musco. 2005. Polychaetes as environmental indicators revisited. Mar. Pollut. Bull. 50: 1153-1162. doi:10.1016/j.marpolbul.2005.08.003

Górska, B., and M. Włodarska-Kowalczuk. 2017. Food and disturbance effects on Arctic benthic biomass and production size spectra. Prog. Oceanogr. 152: 50-61. doi:10.1016/j. pocean.2017.02.005

Hartmann-Schroder, G. 1996. Annelida, Borstenwurmer, Polychaeta, p. 648. In Die Tierwelt Deutschlands. Gustav Fisher Verlag.

Heip, C., and R. Herman. 1979. Production of Nereis diversicolor O. F. Miiller ( Polychaeta ) in a shallow brackisch-water pond. Estuar. Coast. Mar. Sci. 8: 297-305. doi:10.1016/ 0302-3524(79)90047-1

Hjörleifsson, E., and G. Klein-MacPhee. 1992. Estimation of live standard length of winter flounder Pleuronectes americanus larvae from formalin-preserved, ethanol-preserved and frozen specimens. Mar. Ecol. Prog. Ser. 82: 13-19. doi: 10.3354/meps082013

Holthe, T. 1986. Polychaeta Terebellomorpha, p. 1-192. In Marine invertebrates of Scandinavia. Brill.

Hua, E., Z. Zhang, R. M. Warwick, K. Deng, K. Lin, R. Wang, and Z. Yu. 2013. Pattern of benthic biomass size spectra from shallow waters in the East China seas. Mar. Biol. 160: 1723-1736. doi:10.1007/s00227-013-2224-6

Hutchings, P. 1998. Biodiversity and functioning of polychaetes in benthic sediments. Biodivers. Conserv. 7: 1133-1145. doi:10.1023/A:1008871430178

Ieno, E., J. P. Martin, and R. Bastida. 2000. Estimation of size classes in Laeonereis acuta (Polychaeta: Nereididae) based on jaw length and body width usable in trophic studies. Bull. Mar. Sci. 67: 39-43.

Jirkov, I. A. 2001. Polikhety severnogo Ledovitogo Okeana. Yanus-K. [Polychaeta of the Arctic Ocean]
Kapiris, K., H. Miliou, and M. Moraitou-Apostolopoulou. 1997. Effects of formaldehyde preservation on biometrical characters, biomass and biochemical composition of Acartia clausi (Copepoda, Calanoida). Helgoländer Meeresun. 51: 95-106. doi:10.1007/BF02908757

Kędra, M., K. Pabis, S. Gromisz, and J. M. Węsławski. 2013. Distribution patterns of polychaete fauna in an Arctic fjord (Hornsund, Spitsbergen). Polar Biol. 36: 1463-1472. doi: 10.1007/s00300-013-1366-9

Klages, M., A. Boetius, J. P. Christensen, H. Deubel, D. Piepenburg, I. Schewe, and T. Soltwedel. 2004. The benthos of Arctic seas and its role for the organic carbon cycle at the seafloor, p. 139-167. In R. Stein and R. W. MacDonald [eds.], The organic carbon cycle in the Arctic Ocean. Springer. doi:10.1007/978-3-642-18912-8_6

Kukliński, P. 2013. Biodiversity and abundance patterns of rock encrusting fauna in a temperate fjord. Mar. Environ. Res. 87-88: 61-72. doi:10.1016/j.marenvres.2013.03.005

Leuven, R. S., T. C. Brock, and H. A. van Druten. 1985. Effects of preservation on dry-and ash-free dry weight biomass of some common aquatic macro-invertebrates. Hydrobiologia 127: 151-159. doi:10.1007/BF00004193

Martin, J. P., and R. Bastida. 2006. Population structure, growth and production of Laeonereis culveri (Nereididae: Polychaeta) in tidal flats of Río de la Plata estuary, Argentina. J. Mar. Biol. Assoc. UK 86: 235-244. doi:10.1017/ s0025315406013087

Mistri, M., E. A. Fano, and R. Rossi. 2001. Macrofaunal secondary production in a lagoon of the Po River Delta: An evaluation of estimation methods. Ital. J. Zool. 68: 147-151. doi: 10.1080/11250000109356399

Morata, N., E. Michaud, and M. Włodarska-Kowalczuk. 2013. Impact of early food input on the Arctic benthos activities during the polar night. Polar Biol. 38: 99-114. doi:10.1007/ s00300-013-1414-5

Occhioni, G. E., A. C. S. Brasil, and A. F. B. Araújo. 2009. Morphometric study of Phragmatopoma caudata (Polychaeta: Sabellida: Sabellariidae). Fortschr. Zool. 26: 739-746. doi:10.1590/S1984-46702009000400019

Oliveira, V. M., C. S. G. Santos, P. C. Lana, and M. G. Camargo. 2010. Morphological variations caused by fixation techniques may lead to taxonomic confusion in Laeonereis (Polychaeta: Nereididae). Zoologia (Curitiba, Impresso) 27: 146-150. doi:10.1590/S1984-46702010000100022

Omena, E. P., and A. C. Z. Amaral. 2001. Morphometric study of the nereidid Laeonereis acuta (Annelida: Polychaeta). J. Mar. Biol. Assoc. UK 81: 423. doi:10.1017/ S0025315401004040

Pardo, E. V., L. L. S. Teixeira, and A. C. Z. Amaral. 2010. Morphometric analysis of Capitella capitata (Polychaeta, Capitellidae). Iheringia. Sér. Zool. 100: 13-18. doi:10.1590/ S0073-47212010000100002

Paterson, G. L. J., A. G. Glover, and C. Tillman. 2006. Body size response of abyssal polychaetes to different nutrient 
regimes, p. 319-330. In R. Sarda, G. San Martin, E. Lopez, D. Martin, and D. George [eds.], Scientific advances in Polychaete research. CSIC.

Queirós, A. M., J. G. Hiddink, M. J. Kaiser, and H. Hinz. 2006. Effects of chronic bottom trawling disturbance on benthic biomass, production and size spectra in different habitats. J. Exp. Mar. Biol. Ecol. 335: 91-103. doi:10.1016/j. jembe.2006.03.001

Rettob, M. 2012. Fecundity and the body length of rag worm, Perinereis cultrifera (Grube 1840) from Wearlilir beach waters, small Kei islands, Southeast Maluku district. J. Coast. Dev. 16: 84-88.

Robinson, L. A., and others. 2010. Length-weight relationships of 216 North Sea benthic invertebrates and fish. J. Mar. Biol. Assoc. UK 90: 95-104. doi:10.1017/ S0025315409991408

Rosati, I., E. Barbone, and A. Basset. 2012. Length-mass relationships for transitional water benthic macroinvertebrates in Mediterranean and Black Sea ecosystems. Estuar. Coast. Shelf Sci. 113: 231-239. doi:10.1016/j.ecss.2012.08.008

Snelgrove, P. V. R. 1997. The importance of marine sediment biodiversity in ecosystem processes. Ambio 26: 578-583.

Speybroeck, J., L. Alsteens, M. Vincx, and S. Degraer. 2007. Understanding the life of a sandy beach polychaete of functional importance-Scolelepis squamata (Polychaeta: Spionidae) on Belgian sandy beaches (northeastern Atlantic, North Sea). Estuar. Coast. Shelf Sci. 74: 109-118. doi: 10.1016/j.ecss.2007.04.002

Tod, S. P., and J. M. Schmid-Araya. 2009. Meiofauna versus macrofauna: Secondary production of invertebrates in a lowland chalk stream. Limnol. Oceanogr. 54: 450-456. doi: 10.4319/1o.2009.54.2.0450

Weidhase, M., C. Helm, and C. Bleidorn. 2015. Morphological investigations of posttraumatic regeneration in Timarete cf. punctata (Annelida: Cirratulidae). Zool. Lett. 1: 20. doi: 10.1186/s40851-015-0023-2

Wetzel, M. A., H. Leuchs, and J. H. E. Koop. 2005. Preservation effects on wet weight, dry weight, and ash-free dry weight biomass estimates of four common estuarine macro-invertebrates: No difference between ethanol and formalin. Helgol. Mar. Res. 59: 206-213. doi:10.1007/s10152-005-0220-z

Włodarska-Kowalczuk, M., and T. H. Pearson. 2004. Softbottom macrobenthic faunal associations and factors affecting species distributions in an Arctic glacial fjord (Kongsfjord, Spitsbergen). Polar Biol. 27: 155-167. doi: 10.1007/s00300-003-0568-y

Włodarska-Kowalczuk, M., and M. Kędra. 2007. Surrogacy in natural patterns of benthic distribution and diversity: Selected taxa versus lower taxonomic resolution. Mar. Ecol. Prog. Ser. 351: 53-63. doi:10.3354/meps07127

Włodarska-Kowalczuk, M., P. Kukliński, M. Ronowicz, J. Legeżyńska, and S. Gromisz. 2009. Assessing species richness of macrofauna associated with macroalgae in Arctic kelp forests (hornsund, svalbard). Polar Biol. 32: 897-905. doi:10.1007/s00300-009-0590-9

WoRMS Editorial Board. 2018. World register of marine species. VLIZ [Accessed 2018 December 01]. Available from http://www.marinespecies.org

Zaborska, A., M. Włodarska-Kowalczuk, J. Legeżyńska, E. Jankowska, A. Winogradow, and K. Deja. 2018. Sedimentary organic matter sources, benthic consumption and burial in West Spitsbergen fjords-signs of maturing of Arctic fjordic systems? J. Mar. Syst. 180: 112-123. doi:10.1016/ j.jmarsys.2016.11.005

\section{Acknowledgments}

The research leading to these results has received funding from the Polish-Norwegian Research Program operated by the National Center for Research and Development under the Norwegian Financial Mechanism 2009-2014 in the frame of project contract Pol-Nor/201992/93/2014 (DWARF) and from the National Science Center granted based on the decisions numbers DEC-2012/05/B/NZ8/02654 (BIOSIZE) and UMO2016/21/N/NZ8/01385 (DeepClim). The publication has been financed from the funds of the Leading National Research Centre (KNOW) received by the Centre for Polar Studies for the period 2014-2018 and from Statutory funds of Institute of Oceanology Polish Academy of Sciences.

\section{Conflict of Interest}

None declared.
Submitted 04 September 2018 Revised 17 January 2019 Accepted 21 January 2019

Associate editor: George Waldbusser 